\title{
How Politics Become Personal: Sociohistorical Events and their Meanings in People's Lives
}

\author{
Abigail J. Stewart* and David G. Winter \\ University of Michigan

\section{Donna Henderson-King and Eaaron Henderson-King \\ Grand Valley State University}

Major social and political events occurring in adolescence and young adulthood can create politicized identities in particular age cohorts, but within a generation, the experiences and results may differ as a function of different social identities based on (for example) race and gender. We explore the recollections in middle age of experiences in adolescence and young adulthood of four 1968 high school graduates, one from each intersection of race (African American and White) and gender. Most were strongly affected by the civil rights and women's movements, and the Vietnam War-but in ways that reflected both commonalities and distinctive features. The results support existing theories of generational identity and intersectionality, while at the same time suggesting more fine-grained questions for future research.

Baby boomers came of age during a period of intense political conflict in the United States - conflict about race and civil rights, gender and women's rights, and the war in Vietnam (Stewart \& Torges, 2006). While only a small proportion of people become intensely interested in politics in any generation, belonging to a generation that witnesses significant social change has been associated with a greater tendency to feel politicized, i.e., that social and political events have personal significance (Stewart \& Healy, 1989). Considerable research has examined the sources of politicization of activists who came of age in the baby boom (Cole, Zucker \& Ostrove, 1998; Franz \& McClelland, 1994). Our interest is different.

\footnotetext{
* Correspondence concerning this article should be addressed to Abigail J. Stewart, Psychology Department, University of Michigan, 535 Church St. Ann Arbor, MI 48109 [e-mail: abbystew @umich.edu].

We are grateful to Amanda Lewis for her outstanding interviewing of participants, and to the participants for their generous cooperation.
} 
We are interested in how ordinary members of this generation-people who were not activists-experienced the sociohistorical events that coincided with their late adolescence/early adulthood. This period, coinciding with identity formation, has been identified as a formative one for developing a sense of political generation, in cohorts that experience significant social change (Sears \& Levy, 2003).

Sociologist Karl Mannheim (1927/1952) noted that generations are not uniform; subgroups within the same generation ("generation units") react to particular social changes differently. For example, the Vietnam war may have affected those who fought in it very differently than it affected those who protested it. We can expand Mannheim's notion of intragenerational differences by adding the notions of intersectionality and standpoints (Case, Iuzzini, \& Hopkins, 2012; Cole, 2009; Shields, 2008). Feminist theorists of color and critical race theorists have argued that when different axes of power that are associated with social group identities such as race and gender intersect, each group has a different standpoint from which to observe and interpret social events (Collins, 1991; Harding, 1991; Stewart, 2003). Thus the 1960s challenges to conventional authority were uncomfortable or threatening to some White men, whose standpoint reflected both race- and gender-linked privilege (Pratto \& Stewart, 2012). In contrast, White women's standpoint—race-linked privilege but gender-linked disadvantage-was more complicated, sometimes generating rejection of sexism, while being vulnerable to racism but also capable of recognizing some parallel experiences of African Americans (Case, 2012; Montgomery \& Stewart, 2012). African American men, whose standpoint was also complicated-race-linked disadvantage but gender-linked privilege- - had the potential both to reject racism, while being vulnerable to sexism, but also the capability of recognizing some parallel experiences of women and other subordinate groups (Dottolo \& Stewart, 2008). Finally, the standpoint of African American women involved both gender- and race-linked disadvantage (Purdie-Vaughns \& Eibach, 2008). Many have argued that these separate intersections are qualitatively distinct and cannot adequately be understood in additive terms (Cole, 2009; Deaux \& Stewart, 2001); thus, African American women have a unique perspective on social events, which is not simply the sum of White women's experience of gender and African American men's experience of race.

In this article, we examine the recalled impact of social-historical events associated with the 1960s in a small sample of European American and African American men and women who graduated in 1968 from a large, racially integrated public high school in Oak Valley, a large city in the American Midwest. In order to articulate the specific intersectional meaning of those experiences, we chose the memories of four people to examine in detail. Our goal is to use case studies to illuminate how developmental stage, generation and social identities defined by the intersections of race and gender combine with particular kinds of exposure to sociohistorical events to create politicized meanings. 
We focus on the graduates' exposure to three major events associated with the late 1960s and early 1970s: the civil rights movement, the Vietnam War, and the women's movement. For any generation, the significance of events experienced at early stages in the life course can only be assessed in retrospect. By examining people's retrospective accounts of sociohistorical events, we suggest how those events did (or did not) acquire ongoing personal significance.

\section{Method}

The 37 participants in this study were drawn from four groups defined by the intersections of race and gender: African American men $(n=8)$ and women $(n=7)$, and White men $(n=9)$ and women $(n=13)$. When they were in their early fifties they were interviewed about their recollections of important social and historical events and their subsequent importance in their lives (see Stewart, 2003, for details of the data collection). Specifically they were asked: "Looking back over your life, are there social events or movements that stand out as having been particularly important to you?" Interviewers were advised to probe for events that took place "When you were a kid (e.g., the Korean War, McCarthy, Eisenhower's Presidency, the Civil Rights movement, Kennedy's Presidency)" and "When you were a young adult (e.g., women's movement, Vietnam War, any later events)." Participants also described more broadly their childhood, family, and high school experiences, as well as their current activities.

We formally coded the 35 interviews that contained accounts of social and historical events in terms of their topic (e.g., civil rights movement, Vietnam war, etc.), and their autobiographical consequentiality (see Mackavey, Stewart, \& Malley, 1991), defined as having had a great impact not merely at the time but over the rest of their lives, shaping values, political beliefs, activities, or the kind of person they had become.

Three authors (AJS, DGW, DHK) coded all interviews for events referenced and autobiographical consequentiality. Inter-rater agreement, calculated conservatively as percent agreement on the presence of a category (recommended by Smith, 1992, p. 529), averaged above .85; all disagreements were resolved by discussion.

\section{Results}

A brief analysis of the responses from all participants serves as a context for the case studies. Interviewees discussed an average of three events: by far the most frequent were those associated with the civil rights movement (over 85\%) and the Vietnam War (about 75\%). References to President Kennedy or his brother Robert were also frequent (about 69\%). Finally, the women's movement was discussed by only $33 \%$, but in $67 \%$ of interviews with White women. 
Fully half of the interviews described at least one event as autobiographically consequential and politicizing_most frequently Civil Rights Movement events and the Vietnam War, in both cases more often by African Americans. Some White women described the women's movement as having been consequential. All three events were extended in time, controversial in U.S. society, and involved passionately held convictions. Although the four gender-race groups did not differ in number of political and social events or movements recalled, White men were far less likely to describe events as personally consequential. Only $11 \%$ of White men (one man) mentioned any consequential event, compared to 54\% of the combined other three groups ( 6 of 12 White women, 4 out of 7 each of African American men and women). Focusing particularly on the events described as consequential, we selected four interviews - one from each intersection of race and gender- that provided clear and typical accounts of how personal political meaning may or may not develop "on the ground" and over time.

\section{The Four Cases}

\section{Martin: African American Man}

At the time of the interview, Martin was a politically aware African American male who had lived in Oak Valley all his life. His father was raised in the South in a family that was highly educated and affluent; his mother, in contrast, was born into a poor, rural Southern family. Martin continued the tradition of his father's side of the family: highly educated, successful in his chosen career, and financially well off. The 1960s in general, but the Black Power Movement in particular, had a significant impact on Martin's political identity and attitudes regarding intergroup relations for the rest of his life. About African American experience in the 1960s, he stated that the events of the civil rights movement were central in creating a sense of pride and inspiring his generation. His experience with the movement deepened the pride that his parents and extended family instilled in him. Throughout his interview the concept of pride was a consistent theme: he used the term 15 times, in a variety of contexts (e.g., pride in his current job status, pride that his father's family included some of the first African Americans in the South to receive college degrees, and the need to instill pride in his children).

Martin's parents instilled his desire to be known and to have an impact in the world, but his friends and people he encountered outside the home-in high school and college-led him to his political awakening. According to Martin, he and his parents rarely discussed political events and he didn't think they knew about the political activities in which he and his friends participated.

When discussing his own exposure to the civil rights movement of the 1960s, Martin differentiated between the nonviolent wing of the movement epitomized by Martin Luther King, the proviolence wing (e.g., the Black Panther Party), and 
Black Power as exemplified by Black Muslims. This latter wing of the movement became central to his development:

There was an identity thing-pride. Then you had the Black Muslims. That was a huge movement... you would drive anywhere in the Black community and see these guys on the corners selling papers with suits on and bow ties .... We had a mosque ... . I used to go in there with some of our friends-we'd sit for hours, just listening .... Those times were amazing times - the reaction of people and the pride thing, from a national perspective, a lot of things changed.

He later added, "the thing I learned about the Muslim movement was the importance of owning your own business. They stressed nice things. Feeling good about yourself."

Martin also attributed his desire and tendency to critique the status quo and challenge authority figures to what he learned from the Black Power Movement. He described how he and his friends used what they had learned outside of the established educational system to challenge authority figures inside the system. "We used this ... too for our advantage ... . Doctor X, he told us we had to learn the cities of Africa. You can imagine, how many cities [there are] in Africa. So we told him ... 'How is this relevant to us as Black people in America?'"

Martin went on to discuss the sense of power and collective solidarity that he and his fellow students experienced and how this power was nourished by elements outside of the traditional educational system, people in the Black Power Movement, "who would prep us: 'Ask this question."” Martin pointed to the lasting impact of Black Power in his life, reporting "I taught my two children ... never to feel inferior ... the Black Power Movement was all about pride."

Another significant event that Martin remembered was the assassination of Martin Luther King. Martin had vivid memories of the fights that broke out in the days after the assassination. He said that the principal asked him and other senior students to assist in quelling the unrest in the school afterward.

Overall, Martin described the period of the 1960s as a critical juncture in his life, the lives of African Americans, and of Americans in general. "I'm just ... there's been no time like the sixties. And it's the history of this country ... the sixties were amazing times, they really were."

One of the ways that Martin's political consciousness shaped his adult life is that his personal recognition of racism and its effects generated a broader understanding of how other marginalized groups are similarly vulnerable. For example, in discussing his attitude toward homosexuality, he argued that if people had been discriminated against because of their race they could not in good conscience discriminate against others. Thus, while he was not gay himself, in his view, "if that's their lifestyle and that's what they are, then that's their business." He felt that women have also been treated unfairly. "How can I be appalled and bothered by racial discrimination and I'm going to discriminate myself? And not 
only that, but women, you know, how women have been mistreated. The job market and athletics. So, you know, I fight really hard to treat people fairly."

\section{Monica: African American Woman}

Early in the interview Monica expressed her pride in having become a college teacher, but she was equally proud of her community outreach efforts on behalf of AIDS. She also commented about changes in Oak Valley since she was in high school, noting that although it "has come a long way, there's still things that are not good that I see happening, such as racial profiling." She pointed out a myriad of race-related community issues: the need for more Black representation on school boards, city government, the police, and as teachers in the schools, and the need for more community services. More than many interviewees, Monica seemed "plugged in" to the political life of the city and the needs of the Black community.

Monica described her parents as having moved North from the deep South shortly after her birth, to provide their children with an environment they hoped would be both safer and filled with more opportunities. She explained that "our parents knew that we would need an education in order to be successful," though they themselves had little formal education and did hard physical work. Monica recalled family dinners as "wonderful," with good food and conversation. She outlined a particularly vivid and specific "flashbulb" memory of a family dinner:

I remember us talking. One thing that comes to mind, like 1968, coming home and hearing about Martin Luther King being murdered. My mom and dad were so upset ... and I remember my mom especially crying. And it was like we talked about this over dinner. And they were saying, we're getting ready to have turbulent times. They kept saying, "this is going to be a mess." And they kept saying that. "Just be careful wherever you go because this could cause a big mess."

Indeed, the King assassination was followed by turbulent times, as her parents predicted; Monica reacted to this big change in her world by becoming intensely vigilant:

I didn't grow up in situations where you saw people fighting and looting. I kept thinking, could they come here and loot our home and could there be fires at our store right up the street? And I was very, very conscious about listening to the news. I just wanted to keep updated on what was happening, or what's going to happen next.

Monica described this period as "a very awakening time," a time when she recognized her prior sense of safety as temporary, and felt the importance of trying to understand the confusing ongoing events. She was baffled both by the destructive actions of people inside their own communities, and also by the rise of anti-civil-rights activism by George Wallace and others. As she put it, "It really made you more concerned about political issues." Monica described the King assassination as defining a turning point in her life; his death "saddened my 
heart," but it also made her a lifelong follower of politics. She linked the aftermath of King's murder to the community response to the Rodney King beating over two decades later, as well as to contemporary terrorism. In the language of the current political environment, she pointed out that, "As much as we talk about diversity, it's not happening. There's still tension, there's still turmoil between nations, between races, between people."

When asked about other events, Monica quickly mentioned her parents' reaction to "the death of Kennedy. I know my parents-they considered Kennedy one of the good men.... They pretty much felt that his beliefs were for the betterment of the minority race." But it was the killing of Martin Luther King that was a profound catalyst for Monica's politicization. Part of the reason may lie in the combination of her parents' successful creation of a "safety zone" for her and her family, their pattern of talking about social and political issues with their children, and their focus at the time of his death on the coming "turbulence." In addition, however, Monica outlined in detail her parents' equally successful creation of both a positive racial identity in her, and an understanding that race relations in the United States probably would not always result in fair treatment for her. She described their teaching this way:

They told us that there probably would be times in our lives that we may come across some inconsistencies in our lives and that things will probably be unfair. And it could be Whites against Blacks. Because that is just the way that it is. It's been that way since we were born, and that you will probably see that in your lifetime as well. And they always told us not to hate.

This complex message, coupling racial pride and religious values with an understanding of the prospect and reality of discrimination, included advice about how to cope with unfairness when it happened. Her parents advised their children "first go to pray"-advice that Monica continues to take. "After that, then if you really feel that you have been discriminated upon, they said, then you do something in your power to try to change it. And they said, always connect yourself with people that you know that will be a help to you."

Monica took her parents' complex perspective to heart and it empowers her still—both to bear the racism she witnesses and experiences, and to remain politically conscious and active, deeply engaged in the Black community in her city, and to remain open to the possibilities in other people.

\section{Rita: White Woman}

At the time of her interview, Rita was working within the justice system and sitting on the board of a community branch of an international philanthropic organization. She is a politically and socially aware White woman whose career life has been embedded in the community of Oak Valley. Her conversation slipped easily between personal matters and sociopolitical issues; politics were woven into 
the way she thought about her life. The initial forces in Rita's political socialization were her parents. Rita did not "go through a period of rebellion" because her parents paved the way for politicized thinking and activity and encouraged their children to learn and think independently. Her parents supported the civil rights movement, were involved in organizing the Freedom Rides, and actively protested against the Vietnam war. Her mother, in particular, "was always a very self-educated woman. At that time she was the only person in Oak Valley who knew anything about Vietnam. So by the time the protests came in the late 1960s and early 1970s, my parents were heading up the march."

Besides modeling political involvement, Rita's parents exposed their children to cultural and social diversity. For example, they created an environment that was welcoming and comfortable for foreign visitors as well as their children's friends. Adults mingled upstairs and the kids were downstairs. "They pulled out a pool table and a ping pong table, and about twenty ashtrays, and that was where all of us hung out." The whole family was exposed to varying perspectives and Rita enjoyed being at home because it "was where things were hopping." Her parents were also explicit about valuing diversity. Rather than simply spouting platitudes or talking about the importance of tolerance, they found connections with people who had different backgrounds and experiences to be personally valuable and intellectually stimulating. They urged their children to pursue such connections for the same reasons. "My mother encouraged us to enter into interracial dating when I was in high school. She thought that it would be interesting."

While Rita's parents communicated values and created norms that encouraged an interest in "otherness," they didn't challenge the local religious norms of Christianity and church attendance. The church was also a site in which Rita experienced diversity. "I was in the choir and we did a lot of traveling around. That was another area where we came to mix. We would go to Black churches on Sundays, so I got a good feel for the rhythm of the Black church services." While church attendance was crucial, it was the lessons to be learned from teachings of Jesus that mattered most to her parents. "We studied the life of Jesus and what he said. He said we were supposed to love each other... give your coat to the stranger ... . My parents expected us to do that stuff. And they tried to do it too." The message about loving others endured throughout Rita's life. She said about her work with clients, "I think the basics of the religion sunk in, because I try . . to remember that I'm supposed to love everybody and not just the lovable."

Rita further developed her political awareness in high school. Just as her parents encouraged, she interacted with kids who were different from her. She noted that "The Black students at that time were listening to Stokely Carmichael and H. Rap Brown. They were reading a lot, they were learning a lot, and they taught us, and we were anxious to learn." The contact she had with African American students at Midwest High provided opportunities for real discussion about the role of race in the American experience. Rita took an analytical approach 
and, though interested in and sympathetic to the views of her African American peers, her own developing awareness sometimes bumped up against the racebased critique of other students. "They'd say, 'Well, I'll never get a chance at such and such.' Well, you know what? Neither will I. You think I'm going to be President of the United States? I don't think so." All of this was made possible, or at least easier, because of her African American peers' willingness to engage in real dialogue. Rita remembers "seeing each other, talking to each other, listening to each other." Her experiences led to analyses and views that were grounded in a sense of pragmatic realism and critical questioning rather than adherence to a "party line." She recognized the complexity of social and political issues and, like her parents, sometimes expressed ambivalence about them.

The Vietnam War and social movements of the late 1960s significantly affected Rita's thinking. The way the war was fought conflicted with her previous views of the United States as a country based on Christian morality, prompting a recognition that the United States had never been as good as she and other Americans had thought. Her reaction to the war, its supporters, the military and government "became a sense of rage that we were doing that to these people, and we couldn't make them stop ... we were angry that not only were they doing it, but that they didn't care." As a result of the war "we began to question a lot of things that we had been told. And then every little rock got turned over to see what nasty little bug was lying underneath." Her questioning of United States policy extended to the Reagan era and the Iraq war. The women's movement was something Rita learned about on her own. She first noticed articles in magazines and then, much like her mother, educated herself by reading books. This "affected me profoundly" and had an impact on the politics of her personal life.

Rita conveyed that politicization during her teenage years and beyond was a routine part of growing up in a family that "did politics" on a daily basis. The family would listen to the radio and "then we would debate, and there was constantly debate about religion, about politics, about philosophy. And if you couldn't hold up your end, you'd be trounced. My mother would trounce us. Until we could learn to defend ourselves. And sometimes it was friendly discussion .... But it was always challenging."

\section{Matt: White Man}

Matt grew up in a relatively affluent and homogeneously White part of the Midwest High School district. His parents stressed having a "good work ethic, integrity, and stuff like that," but did not encourage an interest in the larger political or social world. Asked about family conversations at dinner, Matt replied that "I don't think we ever talked about world politics, but it was pretty much what happened at work or at school ... stuff like that." After dinner "My dad would like to sit in his chair and read the paper and listen to the ball game or watch TV," 
whereas "my mom was more attached to the church; that was her main thing, I think."

Matt recalled being "shy" in high school: "I probably could have had a lot more fun as friendships," and "I didn't view dating as a fun thing." A few years after graduation from Midwest, he married a woman from Oak Valley, and after his military service, they returned to Oak Valley, where he has recreated a familyoriented home life. "We thought the parents would want to see the grandkids ... so we just kind of stuck here." "We don't have any plans to move."

Asked to recall events or social movements important to him when growing up, Matt's first response was that "the biggest thing was when [President] Kennedy was shot, because everyone remembers where they were then," but he did not mention any impact on him. Only after prompting did he mention Vietnam: "Funny that I couldn't remember that on my own!" However, he then elaborated its effect exclusively in personal terms:

That was probably one of the biggest things that affected ... my life. Because I think I had decided that I was going to get drafted and I was going to Vietnam and I wasn't coming back. So, there were times when I wouldn't even go out and buy a new [record] album because I thought, "Well, I'm not going to need it," you know? So, yeah, and I think that had [an] effect on when I was in college, how I did there and how everything....

Because he had a low draft lottery number, Matt dropped out of college and enlisted rather than waiting to be drafted. Perhaps as a result, he was based in the United States and did not go to Vietnam. He barely mentioned knowing anyone who fought or died in the war. His first job after moving back to Oak Valley drew on skills learned in the military. After he "got burned out" in that job, he was able to adapt his skills and turn "my hobby into a business" that is "advertised all over the place." He identifies his military experience as having changed him as a person: "I was an only child so I was still kind of meek, but once you get out and go, joining the military, that pretty much helped me mature. I was just a little immature, so I am [now] more mature."

It seems clear that Matt views the Vietnam War as significant because he identifies it with major changes in his educational, family, and career paths, as well as a major transformation of his personality. For all its personal significance, however, Vietnam did not have any politicizing effect on Matt. He did not mention any political beliefs, choices, or insights about the wider world affected by Vietnam. For him, the controversy about the war was something observed at a distance: "It was just there.... Once you got into college, then it was more prevalent because everyone was protesting, and so you knew a lot more about it."

After military service, Matt recreated the family enclave in Oak Valleywhere politics and world affairs were not discussed - that he experienced growing up. In late middle age, as for his parents a generation earlier, "the most important things are probably my business, probably my wife and the relationship there, and helping out the kids" as they establish their adult lives. 
Asked about his memory of the Civil Rights movement, he replied that "yeah, I kind of remember stuff about [it]." "I saw that it was necessary, but it didn't seem to have a big effect on me... . They had good ideas." He did recall an episode of community violence in Oak Valley in the late 1960s, but vaguely and without any suggestion of a long-term impact on him: "I think they just tore up some stuff down on [Main Avenue]. I don't know exactly. I can't remember real clearly.” His memories of the deaths of Martin Luther King and Robert Kennedy are similarly vague: "I am sure it did [have an impact on] a lot of people, but I can't remember what the impact was." Matt did value the "racial experience" of Midwest High and believed the increased ethnic diversity of Oak Valley "makes it better." Still, in his neighborhood growing up "there were no Black people," and in high school he "didn't really have any real Black friends that I could hang out with after school"; and at the time of the interview he lived in a suburb where the high school "only had like one or two Black kids there, so [his children] didn't have a clue what it was like to have a different ethnic thing."

For many reasons-personal temperament, home and family climate, and enough economic privilege to ensure a comfortable life-Matt grew up largely shielded from most of the major social issues of the 1960s. The civil rights movement was observed from a distance. Vietnam did break through that shield, but its significance was confined to his personal life: he did not see combat, and he barely mentioned casualties, controversy, demonstrations, and the antiwar movement-features shared by other White males of his cohort.

\section{Discussion}

We examined four accounts of individuals' experience of social events in their adolescence during the 1960 s in order to illuminate how people who identified with different intersections of race and gender attached personal meaning to certain social events-creating "politicization" in some cases but not in others. We conclude that each case is consistent with some current theoretical understandings, but we also see important future directions for research.

Of course our case studies are drawn from a small sample of White and African American adults of a single generation in one Midwestern community. Moreover, most individuals in this sample were never political activists, though political events did influence them. Without further research, we cannot assume these results generalize to other generations, ethnic groups, communities or regions of the country, or political activists.

Three of the individuals we considered (Martin, Monica, and Rita) felt they were affected by the social events of the 1960s in powerful ways predicted by theories of political socialization. All three reacted with a consciousness of their social location (intersectionality), specifically how their subordinate social identities were implicated in these events. In contrast, Matt reported being rather 
removed from the same events, not finding them particularly influential or personally meaningful. He did recognize that the Vietnam War had changed his choices and opportunities, but he did not react to it with any political analysis or position. In short, these events did not generate "politicization," perhaps in part because of his privileged position in terms of both race and gender.

There are links between the two men and the two women that suggest some commonalities associated with gender. Both men were not particularly tied to family life in their youth, and both were permitted to pursue activities in the public sphere, activities that reflected some aspects of male privilege to operate freely in public space. In contrast, the women reported warm and loving family ties, and being kept closer to home. This pattern of stronger intergenerational ties, weaker peer experiences, and fewer opportunities for "adventure" is often identified with female subordination.

Race is an equally visible vector in these accounts. Both African Americans outline early exposure to discrimination and knowledge of the subordination of African Americans. In contrast, both Whites described privileged family lives unmarked by fear, anxiety or anger. It is easy to see how privilege can both insulate people from the impact of events and make it difficult for them to engage in the political arena-all the more reason to understand in detail the factors that lead some "privileged" people to engage with social justice issues.

Finally, we can see how each individual's specific social location at the intersection of race and gender is reflected in their experience. Being a White male in this generation enabled Matt to ignore many of the social events that so powerfully shaped and defined the other three. While some White men were politicized in the 1960s (Gitlin, 1987; McAdam, 1988), we believe it is important to understand better, in the absence of major social movements, how to increase the number of White men concerned about inequalities that do not affect them directly.

Being a White female in this generation enabled Rita both to develop a consciousness of her own subordination, and to develop a sense of alliance with the struggles of other groups (Greenwood, 2008). Similarly, being an African American male allowed Martin to seek some of the privilege associated with masculinity (affluence, respect, and pride), while also seeking to change racial (and other) inequalities (see Hunter \& Rollins, 2015, for very similar themes among the Tuskegee Airmen). While we have considerable research on poor African American men (e.g., Young, 2006), we need to know more about the work of affluent African American men like Martin who seek to improve their communities.

Being an African American female allowed Monica to identify with the struggles of all subordinate groups, and to seek common ground even with those who had some degree of privilege. Cole (2008) has argued that the capacity for coalition-building is strongest among those, like Monica, with multiple 
subordinate identities. At the same time, Purdie-Vaughns and Eibach (2008) have argued that multiple subordinate identities can lead to "intersectional invisibility," because social categories are perceived most strongly in terms of dominant groups. Those who are members only of subordinate groups get "lost" in social perception. These two arguments together suggest that those with the greatest talent for coalition-building are least likely to be recognized and valued in social and political life. Among our four participants, Monica has the most lively engagement with her community, and is the most involved with addressing persisting structural inequalities. As a result, we suspect that intersectional invisibility is a risk worth learning how to avoid.

In line with previous research, our results suggest that engaging young people in discussions of social inequalities may have long-term beneficial effects on their attitudes and beliefs. While these case studies indicate there is no single path to politicization, exposure to events in the public sphere does sometimes-especially if coupled with family or peer discussion-encourage young people's awareness of social and political issues, and lifelong attention to them. At the same time, these case studies also remind us that without a variety of cognitive and social supports, a sense of personal relevance of social and political life may never develop. It is therefore critical to articulate how different groups are implicated by social movements and social events, if we are to foster a sense of alliance among those not directly affected (see Greenwood, 2015).

\section{References}

Case, K. A. (2012). Discovering the privilege of Whiteness: White women's reflections on antiracist identity and ally behavior. Journal of Social Issues, 68(1), 78-96. doi:10.1111/j.15404560.2011.01737.x.

Case, K. A., Iuzzini, J., \& Hopkins, M. (2012). Systems of privilege: Intersections, awareness, and applications. Journal of Social Issues, 68(1), 1-10.

Cole, E. R. (2008). Coalitions as a model for intersectionality: From practice to theory. Sex Roles, 59, 443-453.

Cole, E. R. (2009). Intersectionality and research in psychology. American Psychologist, 64(3), 170180. doi:10.1037/a0014564.

Cole, E. R., Zucker, A. N., \& Ostrove, J. M. (1998). Political participation and feminist consciousness among women activists of the 1960s. Political Psychology, 19(2), 349-371.

Collins, P. H. (1991). Black feminist thought: Knowledge, consciousness, and the politics of empowerment. NY: Routledge.

Deaux, K., \& Stewart, A. J. (2001). Framing gender identity. In R. K. Unger (Ed.), Handbook of the psychology of women and gender (pp. 84-97). New York: Wiley.

Dottolo, A. L., \& Stewart, A. J. (2008). "Don't ever forget now, you're a Black man in America": Intersections of race, class, and gender in encounters with police. Sex Roles, 59, 350-364.

Franz, C., \& McClelland, D. C. (1994). The life course of women and men active in social protests of the 1960s: A longitudinal study. Journal of Personality and Social Psychology, 66, 196-205.

Gitlin, T. (1987). The sixties: Years of hope, days of rage. New York: Bantam.

Greenwood, R. (2008). Intersectional political consciousness: Appreciation for intra-category differences in discriminatory experiences and group relations. Psychology of Women Quarterly, 32, 36-47. 
Greenwood, R. M. (2015). Remembrance, responsibility, and reparations: The use of emotions in talk about the 1921 Tulsa Race Riot. Journal of Social Issues, 71(2), 338-355.

Harding, S. (1991). Whose science? Whose knowledge? Thinking from women's lives. Ithaca, NY: Cornell University Press.

Hunter, A. G., \& Rollins, A. (2015). We made history: Collective memory and the legacy of the Tuskegee Airmen. Journal of Social Issues, 71(2), 264-278.

Mackavey, W. R., Malley, J. E., \& Stewart, A. J. (1991). Remembering autobiographically consequential experiences: Content analysis of psychologists' accounts of their lives. Psychology and Aging, 6(1), 50-59.

Mannheim, K. (1952). The problem of generations. In Essays on the sociology of knowledge (pp. 276-321). London: Routledge Kegan Paul.

McAdam, D. (1988). Freedom summer. New York: Oxford University Press.

Montgomery, S., \& Stewart, A. J. (2012). Privileged allies in lesbian and gay rights activism: Gender, generation and resistance to heteronormativity. Journal of Social Issues, 68(1), 162-177.

Pratto, F., \& Stewart, A. L. (2012). Group dominance and the half-blindness of privilege. Journal of Social Issues, 68(1), 28-45.

Purdie-Vaughns, V., \& Eibach, R. P. (2008). Intersectional invisibility: The distinctive advantages and disadvantages of multiple subordinate-group identities. Sex Roles, 59(5-6), 377-391.

Sears, D. O., \& Levy, S. (2003). Childhood and adult political development. In D. O. Sears, L. Huddy, \& R. Jervis (Eds.), Oxford Handbook of Political Psychology (pp. 60-109). New York: Oxford University Press.

Shields, S. A. (2008). Gender: An intersectionality perspective. Sex Roles, 59, 301-311.

Smith, C. P. (1992). Motivation and personality. New York: Cambridge University Press.

Stewart, A. J. (2003). 2002 Carolyn Sherif Award Address: Gender, race and generation in a midwest high school: Using ethnographically informed methods in psychology. Psychology of Women Quarterly, 27, 1-11.

Stewart, A. J., \& Healy, J. M. (1989). Linking individual development and social changes. American Psychologist, 44, 30-42.

Stewart, A. J., \& Torges, C. (2006). Social, historical and developmental influences on the psychology of the baby boom at midlife. In S. Whitbourne \& S. Willis (Eds.), The baby boomers grow up: Contemporary perspectives on midlife (pp. 23-44). Mahwah, NJ: Erlbaum.

Young, A. (2006). The minds of marginalized Black men: Making sense of mobility, opportunity and future life chances. Princeton, NJ: Princeton University Press

ABIGAIL J. STEWART is Sandra Schwartz Tangri Distinguished University Professor of Psychology and Women's Studies at the University of Michigan. Her current research examines educated women's lives and personalities; women's movement activism both in the United States and globally; gender, race, and generation; and institutional change in the academy.

DAVID G. WINTER is a professor of psychology at the University of Michigan. His research interests focus on political psychology, including especially how personality and social characteristics are related to political and historical events, the psychological aspects of conflict escalation and war, the motivational bases of leadership, and authoritarianism.

DONNA HENDERSON-KING received her PhD in Social Psychology from the University of Michigan and is currently a professor of psychology at Grand Valley State University in the United States. She has conducted research primarily in the 
areas of feminist and group consciousness, media effects on body image, attitudes about body modification, and meanings of education.

EAARON HENDERSON-KING has a PhD in Social Psychology from the University of Michigan and is an Associate Professor of Social Psychology at Grand Valley State University, USA. His current research interests include the role of the media in self-perception, intergroup relations, and the relationship between perceived threat and attitudes toward surveillance. 